\title{
Mise-en-page to Mise-en-scène: Intersecting Display Strategies in Dada Art Journals and Exhibitions \\ Emily Hage
}

A looming effigy of a German officer sports a pig's head. A girl in a First Communion dress spouts obscene poetry. A mirror entitled Portrait of an Imbecile is hung alongside posters screaming "Down with Art!" and, "Finally open your mind!" The provocative strategies of the dadaists' exhibitions, particularly Berlin's 1920 First International Dada Fair (Erste Internationale Dada-Messe) (fig. 1), are well known. ${ }^{1}$ However, scholars have not explored the importance of Dada art journals, Dada, Der Dada, and Die Schammade, among others, in relation to these unconventional presentations. Dada magazines performed as creative "venues" in their own right that paralleled the strategies of the Dada exhibitions. Probing the dadaists' experimentation with these two media highlights the specific ways in which these artists interrogated display conventions. This analysis enhances current understandings of the Dada movement and the histories of graphic and exhibition design by comparing Dada journals and exhibitions and tracing their interlocking histories with a focus on Zurich, Paris, Cologne, and Berlin, where connections between the two formats were strongest. It contends that display was a central and influential Dada concern that was significantly advanced not only through exhibitionary practices, but also through the journals. The dadaists reinvented the magazine as a transportable, accessible, printed, reproducible, reoriented, and thus fundamentally new kind of exhibition venue as well as a critical means of communication during the First World War and its aftermath, when travel was greatly restricted and communication subject to censorship.

Whereas most scholars examine each center in isolation, this investigation proceeds chronologically and comparatively, foregrounding the similarities

I would like to thank Meredith Malone and Matthew Witkovsky for their suggestions regarding earlier drafts of this paper.

1 The effigy, John Heartfield's and Rudolf Schlichter's "Prussian Archangel” (Preussischer Erzengel) (1920) was a part of the Berlin dadaists' First International Dada Fair in 1920; the girl reading poetry was a part of the 1920 Dada Spring Fair in Cologne; Philippe Soupault submitted an eighteenth-century mirror entitled, "Portrait of an Imbecile" (c. 1920) to the Salon Dada exhibition in Paris in 1921; the posters were hung at the Berlin exhibition.

Dada/Surrealism No. 21 (2017) 
among various centers of this diverse movement without losing sight of each city's individuality. The Dada publications initially derived from regular, singularly located presentations, but by 1918 they began to participate in and contribute to dadaists' defining challenge to conventional considerations of artistic authenticity, originality, and presence. In 1920 and 1921 affiliates in Paris, Berlin, and Cologne overturned such established codes in their exhibitions, thus inviting multiplicity into a realm historically tied to uniqueness. As editors and curators, they developed tactics that pervaded the group's creative practice. They moved away from making unique works of art toward experimental layouts and appeals for active engagement and direct (even destructive) interaction that implicated both their journal and exhibition venues. Integrating analysis of their journals and exhibitions, this essay models an approach for interpreting the dadaists' exceptional presentation strategies, practices that would prove highly influential to later generations.

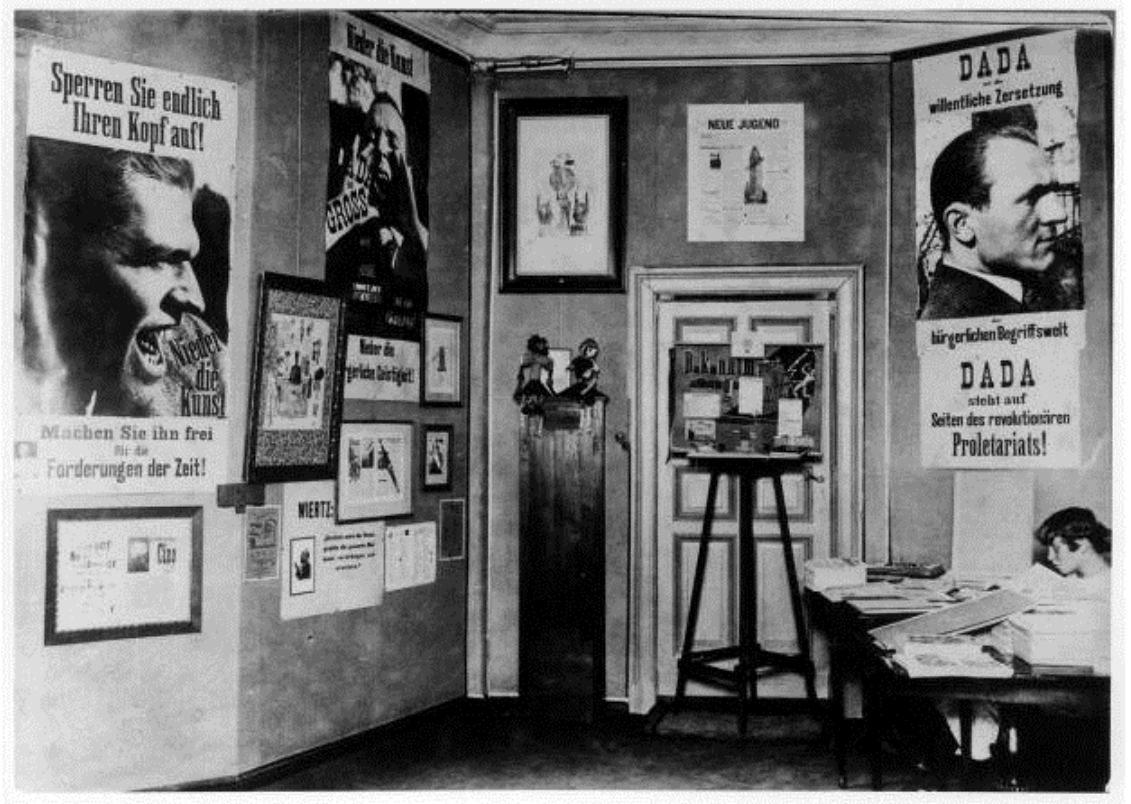

Figure 1: Installation view of the First International Dada Fair, Berlin, Summer 1920, Berlinische Galerie, Berlin, Hannah Höch Archiv [Erste Internationale Dada-Messe, 30.06.1920]. Image courtesy of the Berlinische Galerie, Berlin. 


\section{Launching the Dada Movement: The Journal as Strategy and Venue, 1916 and 1917}

1916 and 1917 witnessed a flurry of exhibitionary practices among the artists, writers, and actors, later identified as dadaists, who gathered in Zurich, including Tristan Tzara, Hugo Ball, Emmy Hennings, Hans (Jean) Arp, and Sophie Taeuber. The walls of the Cabaret Voltaire's smoky, cramped space filled with riotous songs and bizarre performances featured paintings, reliefs, and drawings, as well as less conventional objects like collages, masks, and poems by the budding dadaists as well as cubists and futurists such as Pablo Picasso and Filippo Tommaso Marinetti. Many of the materials had been mailed to Ball, Tzara, and Arp for exhibition but also for publication in the journal Cabaret Voltaire that Ball was planning (Tzara, "Chronique Zürichoise" 235; Grieve 180; Marinetti 22; Ball, Flight 25, Dickerman 23). Although Ball and the others disagreed about the purpose and direction of their collective efforts, the hanging of the works at the cabaret reflected their growing recognition of the potential to creatively combine various visual and textual artworks in a performative space. Details regarding how works were hung are not known, but Tzara's description of the cabaret intimates a certain chaos consistent with the space's atmosphere: “On the walls: van Rees and Arp, Picasso and Eggeling, Segal and Janco, Slodky, Nadelmann, colored papers, ascendancy of the NEW ART, abstract art and geographic futurist map-poems: Marinetti, Cangiullo, Buzzi" (Tzara, "Zurich Chronicle" 235).

By 1917, the Zurich group had relocated to the Galerie Corray, later the Galerie Dada, on the upscale side of Zurich's Limmat River. This space hosted four exhibitions between January and June 1917: the First Dada Exhibition (Première exposition Dada), two shows presenting works from Herwarth Walden's Der Sturm gallery in Berlin, and the Exhibition of Graphic Art, Embroidery, and Reliefs (Ausstellung von Graphik, Broderie, Relief). The dadaists put on events in the gallery, but visitors were required to pay admission fees and alcohol was prohibited, creating a demonstrably more staid environment than that of the Cabaret Voltaire that likely affected the way they displayed works of art.

The turn of the century had witnessed a shift in exhibition techniques from cluttered, salon-style nineteenth-century installations in which works were hung very close to each other, sometimes from floor to ceiling, to early twentieth-century displays featuring fewer and fewer paintings on the walls. Now they were arranged in an orderly fashion, at eye-level, one next to the other, with smaller, horizontal works occasionally stacked two high. The space around individual works also increased so that there could be a few inches to more than a foot between images (Klonk 49-85). While there is little information regarding the specific installation techniques of the Galerie Dada exhibits, they were probably in this modern style, which had been adopted by other galleries for presenting the works of German expressionists and other avant-garde artists in the early twentieth century (Klonk 91-93). A photograph of a 1918 exposition at the 
Kunstsalon Wolfsberg in Zurich, which included Dada contributions, reveals that works were arranged in this way and supports this interpretation.

At this time the Zurich collective also began publishing art journals: Cabaret Voltaire (May 1916), organized by Ball, and the first two issues of Dada (July and December 1917), produced by Tzara. By publishing these journals the dadaists joined a wide network of artists using periodicals to circulate their experimental writings and artworks. The futurists, expressionists, vorticists, cubists, and figures later associated with Dada, such as Francis Picabia and Marcel Duchamp, produced many periodicals that documented and helped realize the avant-garde at this time. Over thirty such journals were published in Paris alone between 1917 and 1923 (Drucker 104). As these movements comprised both artists and writers, the hybrid nature of the magazine, which can include both texts and images, was particularly suited to their efforts. Their periodicals - Lacerba, Der Sturm, 291, The Blind Man, Blast, and 391, to name a few-allowed them to publish their paintings, poems, drawings, and essays alongside one another at a time when perceived boundaries between literature and the visual arts were crumbling. ${ }^{2}$

The earliest Dada periodicals from 1916 and 1917 were distributed at the Dada exhibitions, and in many ways functioned as illustrated catalogues for these events. A German supplement to Dada 1, for example, lists events held at Galerie Dada. Cabaret Voltaire offers a checklist of objects presented at the second exhibition at the Cabaret Voltaire, and both journals include works that appeared in the gallery exhibitions. The journals also, notably, include reproductions of reproductions, or images of works of art copied from previous printings in other contexts. Cabaret Voltaire, for instance, presents a copy of Picasso's etching of a woman that had illustrated Max Jacob's novel, Saint Matorel (1911), a reproduction of a woodcut by Marcel Janco that had been used as a poster for the dadaists' "Chant Nègre" performance in March 1916, and the title page of the program for a Der Sturm exhibition and soirée. ${ }^{3}$ Such images were a part of the the editors' visual landscape, and by including them the editors signaled a certain disregard for the fact that they had been reproduced before.

Cabaret Voltaire and the first two issues of Dada reflect distinctly different views among members of the Zurich group in 1916 and 1917. Ball produced Cabaret

2 Lacerba (Giovanni Papini, Florence, 1913-1915), Der Sturm (Herwarth Walden, Berlin, 19101932), 291 (Alfred Stieglitz, Marius de Zayas, Paul B. Haviland, and Agnes Ernst Meyer, New York, 1915-1916), The Blind Man (Henri-Pierre Roche, Beatrice Wood, and Marcel Duchamp, New York, 1917), Blast (Wyndham Lewis, London, 1914-1915), and 391 (Francis Picabia, Barcelona, New York, Zurich, Paris, 1917-1924).

3 Ball most likely reproduced Picasso's drawing without the artist's permission. Italian artist Enrico Prampolini informed Tzara that Picasso was surprised to see the image in Cabaret Voltaire, and annoyed that his permission had not been asked to reproduce it (Letter to Tzara). 
Voltaire as an anthology of the Zurich group's creative efforts. In his introductory essay to the magazine, he sets out the Zurich group's commitment to internationalism, asserting, "It is intended to present to the public the activities and interests of the Cabaret Voltaire, which has as its sole purpose to draw attention, across the barriers of war and nationalism, to the few independent spirits who live for other ideals." ${ }^{4}$ Like Ball, others in the Zurich group, particularly Richard Huelsenbeck, understood Cabaret Voltaire as an anthology showcasing their individual contributions. Ball's diary entry from the time reads: “H. [Huelsenbeck] speaks out against 'organization'; people have had enough of it, he says. I think so too. One should not turn a whim into an artistic school" (Flight 60). In other entries Ball expresses concern about the potential widening of their audience, moving away from the immediate interaction with people in the cabaret and toward an unknown international audience. Such a shift may have seemed dangerously close to the nationalistic propaganda he so deplored (Dickerman 33).

Nevertheless, the group agreed to publish another magazine. Dada came out a little over a year after Cabaret Voltaire. Huelsenbeck later explained that the very name "Dada" was chosen as "a slogan which might epitomize for a larger pubic the whole complex of our direction" (78). According to Ball, it was his idea to use this word for the journal, which, he indicated, should be edited by rotating editors assigned by a general editorial staff (Flight 63).

Like his fellow collaborators in Zurich, Tzara described Cabaret Voltaire as "not a journal but a documentary publication on the cabaret we founded here" (Letter to Luciano Raimondi, March 17, 1917, qtd. in Dickerman 32). However, for the Romanian poet Cabaret Voltaire, as well as Dada, constituted a valuable means of launching and publicizing Dada as a new movement amidst wartime tumult and travel limitations. Understanding that they could not rely solely on exhibitions to introduce and publicize Dada, Tzara employed the journals as another type of venue.

The publications offered many distinct advantages. Although now considered ephemera, they were not as fleeting as Dada's short-lived exhibitions. Printed, multiple, and portable, they transcend spatial, geographical, and temporal limitations, reaching a wider audience for a longer duration and thereby increasing the level of provocation they could achieve. Although local residents made up the large majority of the attendees at Dada events in Zurich, the magazines enabled communication with targeted audiences in many cities. Most of the texts in the first two issues of Dada are in French and Italian rather than German, the dominant language in Zurich, reflecting Tzara's use of the magazines to establish and maintain relationships with artists, writers, and other magazine editors, primarily in Paris, Rome, and New York. In addition, the physical requirements of shipping original works and the realities of arranging a space navigable for visitors necessarily restricted the range of contributions involved. In

4 Except where noted, all translations are by the author. 
a wartime setting, gathering submissions to be presented in a magazine was a comparatively simpler undertaking; less expensive to produce, it required only materials that could be mailed in an envelope rather than fragile, crated objects.

The magazines also enabled the dadaists to reproduce their works alongside those by established figures from cities around the world, thus declaring and realizing their transnational ambitions that transcended the contested national borders of this period. Tzara also seized upon the journal as particularly suited to the unprecedented heterogeneity of their movement. Instead of defining Dada with manifestoes and outlining specific artistic and ideological tenets, the magazines presented an eclectic mix of styles under the undefined, and undeniably catchy, Dada label, thus taking advantage of the multi-page format of the journal to inaugurate a movement without delimiting it. Finally, this printed medium, like their later planned anthologies, had the potential to provide a record and archive of Dada art, performances, and attitudes, and thus to significantly advance endeavors to establish their artworks and writings, as well as their journals, as part of Dada's creative legacy.

Despite the innovative purposes to which the magazines were put, Cabaret Voltaire and the first two issues of Dada are graphically conservative. Font type, style, and size are consistent within a page, and advertisements are printed apart from essays and poems on the back cover. Texts and images are separated from one another, and entire pages are devoted to a single illustration with a brief caption, emphasizing the work's singularity. This presentation communicates an effort to stage the images as if they were originals and to recreate the experience of modernist exhibitions focused on unique works of art, not reproductions and multiples.

The way that prints were reproduced in the deluxe issues of these magazines also added to the emphasis on singularity. For example, the source of Picasso's etching from Saint Matorel reproduced in Cabaret Voltaire is not revealed, masking the fact that it is a reproduction of a reproduction of a multiple; the Janco print of the "Chant Nègre" in this issue appears without the text that had appeared on the poster. The various woodcuts reproduced in the journal were afforded entire pages, suggesting their uniqueness and value. The focus on one work at a time was also in keeping with experiments among museums and galleries at the turn of the century. The newer kind of installation reflected a preoccupation with visitor experience during this period, and generally encouraged the intimate, interior, individual contemplation of one piece at a time (Klonk 49-85). The journals replicate this kind of focused phenomenological experience.

The style of the Zurich publications resembles the environment of the Galerie Dada and diverges most noticeably from the atmosphere cultivated at the Cabaret Voltaire. The contrast is especially compelling in the case of Cabaret Voltaire, which privileges coherency over the kind of unruliness found in the cabaret itself. The disjunction is especially evident when comparing the three-part simultaneous poem, "L'Admiral cherche une maisone à louer" ("The admiral is looking for a 
house to rent"), as it is printed in Cabaret Voltaire, in straight lines that resemble a musical score, and what must have been a cacophonous performance. At this early moment in the movement, the dadaists aimed for direct, seemingly unmediated communication of the images and texts they presented. Only later would they fully realize the art journal and exhibition as artistic media with enormous creative and critical potential for integration and interconnection.

\section{“Every Page Must Explode": The Journal as Primary Exhibition Venue, 1918-1919}

As the First World War came to an end, travel constraints persisted and individual members participated in only a limited number of group shows at venues such as the Kunstsalon Wolfsberg in Zurich, I. B. Neumann's Graphisches Kabinett in Berlin, and the Bulletin D exhibition at the Cologne Kunstverein. The most widely distributed and influential Dada magazines from this period are Zurich's Dada 3 (Tzara, December 1918) and Dada 4-5 (Tzara and Picabia, May 1919) and in Berlin the first two issues of Der Dada (Raoul Hausmann, June and September 1919). As opportunities for exhibitions decreased but the Dada movement kept expanding, Tzara and the Berlin dadaists began to approach the magazines less as sites of reproduction, documentation, and expected modes of spectatorship and more as active spaces for enacting new modes of creation and reception.

"Every page must explode, either by profound heavy seriousness, the whirlwind, poetic frenzy, the new, the eternal, the crushing joke, enthusiasm for principles, or by the way in which it is printed" ("Dada Manifesto 1918" 78). Tzara's directive from his famous Dada manifesto, first published in Dada 3, conveys the centrality of magazines and inventive graphic design for the dadaists in both Zurich and Berlin, despite growing tensions regarding the leadership and course of the movement (Bergius 88-102).

Dada editors looked to their predecessors and contemporaries in constructing their magazines. Artists such as Stéphane Mallarmé, Guillaume Apollinaire, the expressionists, the futurists, and the vorticists manipulated typography and treated their journals as a creative, potentially interactive medium. ${ }^{5}$ Lacerba, for instance, contains large pages (over a foot high) of parole in libertà, combining different typefaces and font sizes to create explosive, dynamic pages. The vorticists' Blast is printed in a folio format, and texts address readers in a direct, often confrontational manner. Finally, the caricatures, calligrammes, and psychotypes in 291 made it a particularly influential publication. Even in the most inventive examples, however, the experimentation is bracketed, and the title, format, typography, and printing intervals adhere to a uniform format. The printing of the title of Lacerba was unvarying, for instance, with continuous page

5 For more on the history of avant-garde typography in the twentieth century, see Drucker and Bury. 
numbers from issue to issue. In Der Sturm small woodblock images consistently punctuate the texts. Even in the graphically stunning 291, textual and visual entries usually are clearly separated from one another, leaving readers' basic expectations unchallenged. ${ }^{6}$

Dada periodicals from 1918 and 1919, by contrast, upended such expectations. Recognizing that readers navigate printed pages, like gallery walls, by identifying various texts according to their appearance and placement, the dadaists made every effort to make their publications interactive, despite the limitations of the print technology available to them (primarily letterpress). Tzara explained that in Dada 3 "typographic order is ignored," and his characterization describes Dada 45 and the first two issues of Der Dada in Berlin as well ("Les Revues" 509). Texts typically emphasized, such as titles, appear in relatively small print, and type varies arbitrarily within a single text, with random letters printed in bold face, underlined, or surrounded by graphic elements. For example, a single page of Der Dada 2 is printed in seven typefaces and eight sizes.

The dadaists blurred divisions between elements, sabotaging efforts to determine where one ends and another begins. As Tzara explains, "drawings, poems, notes, and advertisements intertwined with one another to make clear the position of the dadaists who, wanting to confuse everything, disregarded aesthetic requirements" ("Les Revues" 509). Texts appear diagonally and perpendicular to one another, so that one must rotate pages to read them. On a page of Dada 3 a dedication to Picabia bumps up against the first line of Tzara's poem, "Bulletin," in the same font type and size, and an announcement for his 25 poèmes (fig. 2) is printed sideways, right next to the poem (Drucker 206-12). Editors appealed to the individual to turn pages around in their hands, so that their eyes jump around among the texts and images at various speeds, effecting what Hanne Bergius has called, in her analysis of Berlin periodicals, "the dynamization of the reading process" (90). They thus compelled readers to consciously recalibrate their expectations regarding font sizes and types, as well as the placement of texts and images and even the very division between support and artwork.

Beginning in 1918 Tzara and Hausmann also began stripping away any kind of framing device for images. In Dada 3, Dada 4-5, and the first two issues of Der Dada images are in dialogue with poems, announcements, and manifestoes, calling attention to the printed nature of the journal as display venue. For instance, the page from Dada 3 mentioned above shows two abstract woodblock prints placed directly alongside texts. Although Arp and Janco are identified, Arp's name is upside down, and there is very little space between figures and letters.

6 One notable exception is a two-page spread in the May 1915 issue of 291 (no. 3) featuring Agnes Ernst Meyer's poem, "Woman," printed at a right angle with a poem by Katharine Nash Rhoades, both of which are framed by a bold triangle of blue ink that sweeps across both pages, accented by a pendulum-like form and a series of intersecting lines, Marius de Zayas's caricature of Rhoades. 


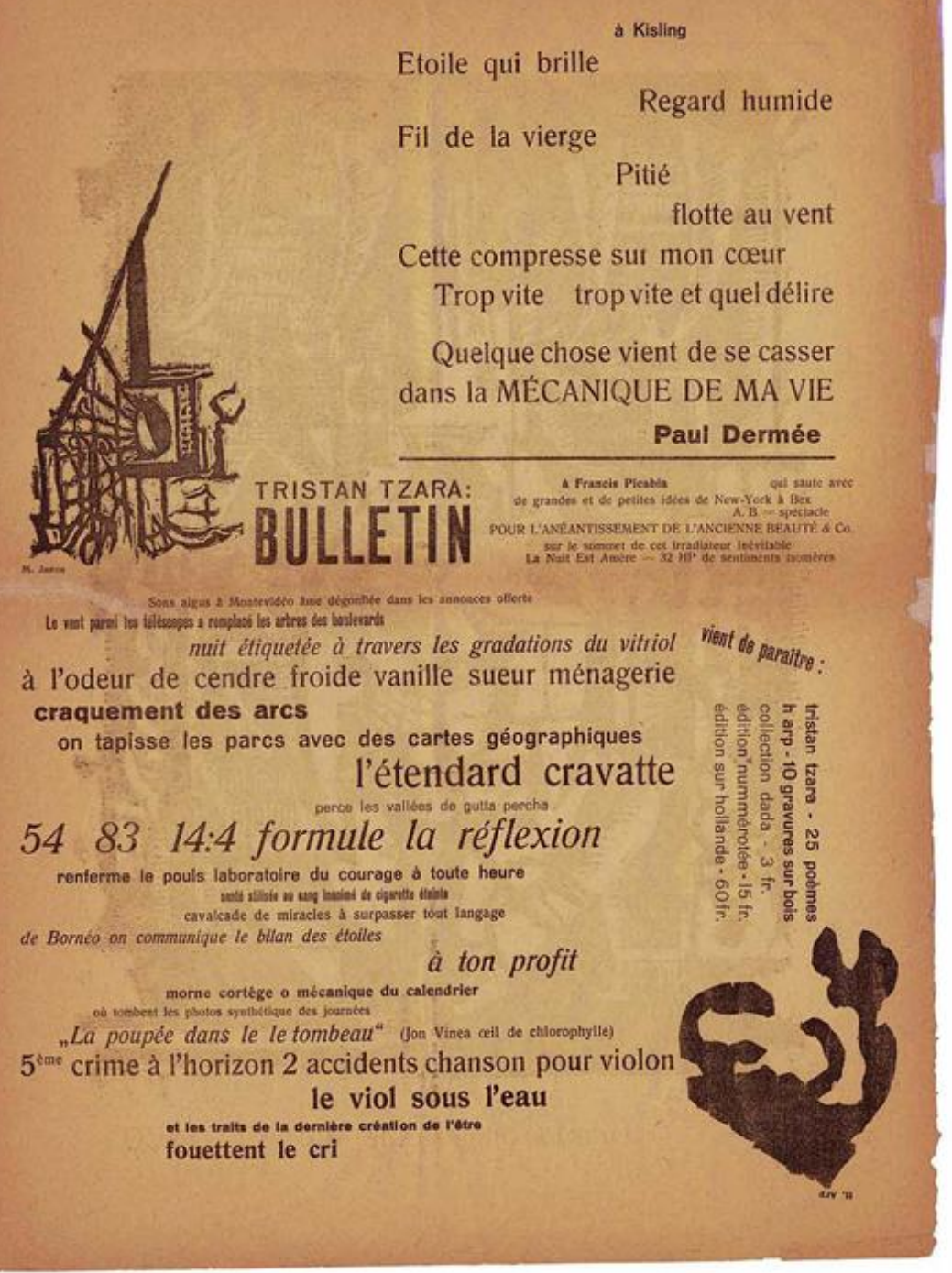

Figure 2: Page thirteen, Dada 3, ed. Tristan Tzara (Zurich, December 1918). International Dada Archive, Special Collections, University of Iowa Libraries.

The pages also stress the nature of text as image. The strong diagonal on the left side of Janco's architectonic, almost calligraphic, composition, for example, accentuates the slope of the lines of the poem below, and the tentacles of Arp's biomorphic shape point toward the advertisement. In Der Dada 1, similarly, a 
woodcut by Hausmann appears unlabeled, and while the texts are uniformly printed, they are indented to accommodate the image. The dadaists in Zurich borrowed many such techniques from advertising, thus simultaneously foregrounding and crossing fiercely defended borders between artistic, journalistic, and commercial sources (Simmons 131). As if to highlight their transgression, they even manipulated layout in selling their Dada publications. The page from Dada 3 forces the reader to turn the page ninety degrees counterclockwise in order to read the ad for 25 poèmes, and Arp's print literally points to it. This flirtation with artful chaos and commercial tactics also proved significant to their later exhibitions.

Dada journal editors assaulted readers' attempts to peruse their publications passively or through traditional modes of reading and spectatorship. The serial nature of the periodical usually leads readers to assume that words and pictures will be presented so that readers can take in each page as easily and in as orderly a fashion as possible before the next page appears or the next issue, already in production, arrives. But by highlighting the visual coding of typography and layout, Dada editors demanded active engagement with the materiality of the magazine as well as a slowing down of the usual process of reading and looking. The dadaists compelled their readers to become active participants rather than complacent observers.

Additionally, rather than serving as absent conduits of images and texts, the dadaists interjected their presence in the journals. In Der Dada 2 Hausmann and Baader present their essay, which bears the imperative title, "Join Dada" ("Tretet Dada bei"), with a photograph of themselves showing Baader staring down the camera. Another page barrages the reader with a string of questions (printed in multiple font types and sizes): “What is Dada? An art? A philosophy? A policy? Fire insurance? Or: a state religion? Is Dada really energy? Or is it nothing at all i.e., everything?" (6) (fig. 3).

The Dada magazines from 1918 and 1919 manifest their editors' growing understanding of the journal as an opportunity to compile multiple kinds of materials, information, and modes of communication on a single page. The pages of their issues of Dada and Der Dada demonstrate a fundamental reorientation, a move from a vertical to a horizontal point of reference. By combining a wide range of texts and images on a given page, the dadaists emphasized that unlike paintings hung in a museum or gallery, where the mode of display brings the viewer into a world that corresponds with his or her upright position, their journals were assemblages of materials arranged for printing, akin to the "flatbed picture plane" Leo Steinberg describes in his famous essay, "Other Criteria." Steinberg writes that artworks from the 1950s and 1960s "insist on a radically new orientation, in which the painted surface is no longer the analogue of the visual experience of nature but of operational processes" (84). 


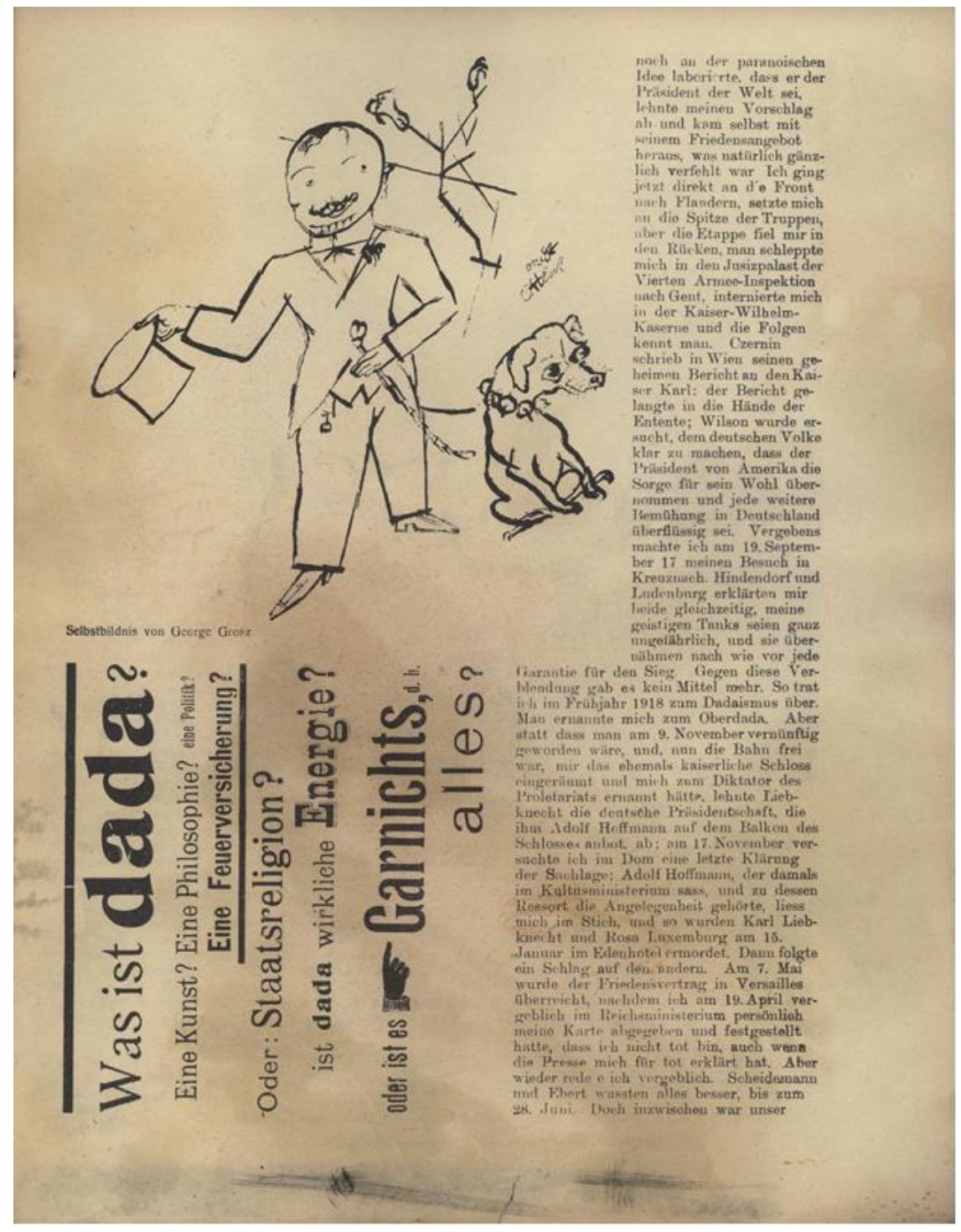

Figure 3: Page 6, Der Dada 2, ed. Raoul Hausmann (September 1919), International Dada Archive, Special Collections, University of Iowa Libraries.

Similarly, these periodicals provided a new kind of exhibition space, one that orients itself toward a larger, more complex network of communication and information, and thereby asks viewers to reorient their own positions. The dadaists had tried to replicate the experience of seeing a given piece in a gallery space in their journals, but now they moved away from an emphasis on trying to approximate the standard phenomenological aims of exhibitions. Instead they 
stressed the potential of the magazine's flexible form by compiling poems, manifestoes, prints, and photographs onto a plate or "receptor surface," as Steinberg calls it (84). Rather than attempting to overcome the materiality of the page to present paintings in a manner as close to the original as possible, they stressed the tactile, opaque, horizontal, inky nature of the printing process and therefore the materiality of the magazine itself. ${ }^{7}$

The journal became for the dadaists a place removed from an original, preceding encounter, or auratic work of art on a wall. In "The Work of Art in the Age of Mechanical Reproduction," Walter Benjamin asserts that the dadaists achieved "a relentless destruction of the aura" (238). The magazines helped catalyze this change. In 1918 and 1919 representatives of the movement in Zurich and Berlin printed fewer and fewer reproductions of pre-existing objects and more and more woodcuts and drawings created specifically for their magazines. Tzara's Dada 3 and Dada 4-5, for example, although they included reproductions of paintings by Wassily Kandinsky, Augusto Giacometti, and Hans Richter, are illustrated primarily with woodcuts by Richter, Arp, Janco, Prampolini, and Arthur Segal. Woodcuts by Hausmann and Berlin dadaist Hannah Höch, as well as a drawing by George Grosz appear in the first two issues of Der Dada.

The dadaists' dependence on these publications also encouraged them to create easily reproducible images, as they understood that the magazine was the primary means by which their works would be circulated. The medium determined the art and this art, in turn, demanded a new kind of mediation. The journal's role migrated from that of an exhibition catalogue to an actual exhibition and work of art.

Rather than considering the journal pages as stable supports for materials, Tzara, Hausmann, and their collaborators also undermined expectations about the very forms through which they presented their images and texts. Instead of merely a transparent substrate for given images or texts, each page now became integral to the works shown, and fodder for further recombination. The collages they reproduced in the journals were made up of photographs, newspapers, and posters, but also pages from other Dada publications. In a collage portrait of poet Paul Gurk, published in Der Dada 2 (1919), for example, Hausmann combined clippings from commercial magazines and newspapers with cutouts of a woodblock print, a photograph, and single letters and phrases, all taken from

\footnotetext{
7 Tzara's publications, however, feature limited edition prints, suggesting that the dadaists had not completely abandoned notions of authenticity. Yet the prints, though handmade, were nevertheless multiple. In the limited issue version of Dada $4 / 5$ a woodblock print by Arp adorns the cover along with the word "Dada" stenciled on a cutout from newspaper classifieds. The combination of various levels of reproducibility and mechanization suggest that the dadaists were questioning ideas regarding authenticity. In addition, regardless of their comparable singularity, these issues were nevertheless presenting the works in a journal, a multiple venue that challenges traditional notions of display.
} 
Tzara's Dada 3. The piece points out that any part of a Dada publication could be cut up and reintegrated into another collage, which, in turn, could be incorporated into another collage or reproduced in a separate Dada one. Such treatment of the journal page calls attention to it and prompts the reader to perceive it as a temporary, dynamic, and destructible surface rather than an unchanging, transparent, blank ground for presenting pictures and texts. Dada journals from 1918 and 1919 most directly undermined print media standards, but their tactics more broadly contested protocols of display.

\section{Exhibiting Ephemera: Intersections Between Dada Journals and Exhibitions, 1920-1921}

By 1920, the dadaists had reached the pinnacle of their fame. In large part because of the journals, their movement was known and promoted in more and more cities, including Paris, Cologne, Rome, and New York. As travel became easier, Dada members began focusing on organizing exhibitions. They applied many of the inventive tactics they had developed in their journals to their exhibitions, again testing the conventions of their chosen medium. Three landmark expositions from this period stand out: the extraordinarily irreverent Dada Early Spring (DadaVorfrühling) exhibition (April 1920), organized in Cologne by Max Ernst and Johannes Baargeld and held in a bar's courtyard, the Berlin dadaists' First International Dada Fair (June 1920) at Dr. Otto Burchard's gallery, produced by Hausmann, John Heartfield, and George Grosz, and Tzara's ironically titled Salon Dada (June 1921) presented at the "Galerie Montaigne" in the Théâtre des ChampsElysées in Paris. ${ }^{8}$

In Cologne, Ernst and Baargeld put together their show after the ostensibly "jury-free" exposition at the Artists' Union (Arbeitsgemeinschaft bildender Künstler) at the Cologne Museum of Arts and Crafts (Kölner Kunstgewerbemuseum) rejected their unconventional submissions. Ernst and Baargeld's works made up most of the exhibits, but it also included works by fellow Cologne artist Willy Fick as well as Arp and Picabia. Its organizers aimed to bring Dada to Cologne, evident in the fact that the catalogue is written in their

8 The dadaists, of course, were not the first to organize their own exhibitions. The German expressionists, Italian futurists, and supremacists, for instance, had designed innovative shows in the years immediately preceding the war. The "First Exhibition of the Editorial Board of Der Blaue Reiter" (Erste Ausstellung der Redaktion Der Blaue Reiter) in Munich in 1911 stands out as it, too, was closely connected to a publication, in this case the Blue Rider Almanach. While in most of these exhibitions works were hung in one or two rows, the famous 0-10, The Last Futurist Exhibition of Pictures in Petrograd (now St. Petersburg) (December 1915-January 1916) showcased the iconic corner placement of Kazimir Malevich's Black Square and the asymmetrical arrangement of the works surrounding it, as well as Vladimir Tatlin's corner counter-reliefs. Such expositions were significant precursors for the dadaists. 
native German. At the same time, the inclusion of Arp and Picabia demonstrates their international ambitions, and hosting a Dada exhibition, as they well knew, helped them gain recognition as a Dada center.

By contrast, in Berlin, where Dada was well established, the exhibition was a culmination of the many Dada activities in the city. The large majority of the works were by the Berlin group, as well as by artists in other European cities, signaling to visitors the movement's international scope. The show, which overtly parodied trade fairs, was more politically motivated. It also highlighted the history of the movement by showcasing earlier posters from past events as well as Dada journals.

Tzara and Picabia (Picabia later withdrew from the exhibition entirely) decided to organize their Paris show as a dissident response to the 1921 Indépendants exhibition, and to accompany three performances. Much as Tzara chose writings by artists in his journals, here he presented artworks by writers (Sanouillet 201), and like the Berlin show, it parodically pitched Dada in commercial terms. The show emphasized enthusiasm for Dada both locally and internationally. ${ }^{9}$ In a city where Dada was well known, the Paris show demonstrated the movement's prankish strategies while reiterating its broad reach and anthologizing its activities and accomplishments, especially evident in the posters from earlier exhibitions that hung above the artworks (Mileaf and Witkovsky 354). Scholars such as Hanne Bergius, Michel Sanouillet, and Sabine Kriebel have analyzed these important exhibitions. Comparing the relationships between these exhibitions and Dada journals reveals how central presentation strategies were to the dadaists and draws out the parallels between their journals and exhibitions.

The Dada exhibitions heralded a shift in the late 1920s away from the aesthetic contemplation of individual works to installations that functioned as public spaces that provoked interaction (Klonk 10, 108; Noordegraaf 92). By this time, artists, notably El Lissitzky, had begun devising innovative installations. Wall colors, for example, were not uniform in a given space, and visitors could move parts of the display. Museum directors and curators, too, were experimenting with different kinds of installations and debating how best to engage visitors (Klonk 8-9). Recognizing that visitors functioned as embodied spectators, they understood that each viewer's experience was determined by his or her actions and that of other gallery visitors in their shared space (Klonk 16; Bal 8; Noordegraaf 16).

The dadaists explored the distinct yet analogous qualities of exhibitions and journals and their different forms of spectatorship. One reads a printed publication, turning pages in a linear fashion regardless of how tangled each spread may be, while the space of an exhibition, despite certain unavoidable

9 Of the twenty-one individuals who submitted the eighty-one works on view, the majority lived in Paris at the time, in addition to affiliates in Cologne, New York, Berlin, and cities throughout Italy. Most of the works were made only for the exhibition and did not last long afterwards. 
barriers, often provides more freedom to determine the order in which one encounters objects. While an exhibition is available for viewing only for a brief period of time, a journal, though categorized as ephemera, has the potential to survive for many subsequent generations.

Despite such differences, the dadaists used many of the same tactics in both their exhibitions and publications, seizing upon their parallels. Both present collections of chosen pieces to serve as major means of producing and disseminating information (Greenberg et al. 1). Both are compiled through collaborative efforts that require requesting, choosing, compiling, and arranging materials, as well as framing and describing these works. Like walking through a three-dimensional exhibition space, leafing through a journal is a public and a private practice, one that an individual undertakes on a personal level yet knows is shared by many, often simultaneously. And while one does not directly encounter other readers while holding a journal, one is nevertheless aware that identical copies of this mechanically reproduced publication will also be handled by others.

As in their journals, in their exhibitions the dadaists hijacked the given standards of these forms of display and turned them on their heads in such a way as to reinvent both as experimental, interactive venues of display. In each of these cities they transformed their venues into chaotic, bewildering spaces parallel to their daring journals. The provocation began with the sheer variety of what they showed. The 1920s Cologne, Berlin, and Paris exhibitions presented a broad assortment of artworks and found objects, from mannequins, ties, a fish tank, a stuffed military uniform, and a chunk of asphalt to posters, handbills, and, significantly, Dada magazines. The Cologne exhibition, its catalogue tells us, included reviews, presumably Dada reviews. At the Dada Fair, the Berlin dadaists exhibited Dada magazines, including Neue Jugend (New Youth) (Wieland Herzefelde and Heartfield, Berlin, 1916-1917), 391 (Francis Picabia, Barcelona, New York, Zurich, Paris, 1917-1924), Der Dada 1 and 3 (Bergius, appendix "First International Dada-Fair" 15, 48, 58, 49, 23, 16).

The organizers of these shows also recognized the importance of exhibition design for how the works, and the movement as a whole, would be understood by visitors. Exhibits overlapped with one another, lay on the ground, loomed overhead, and covered the walls from floor to ceiling. In addition to Heartfield's and Rudolf Schlichter's "Prussian Archangel," which famously hung above visitors at the Berlin Fair, in Paris a mannequin of a man in a suit stood outside of the balcony's railing with one arm extended. Dozens of men's ties hung down below the railing, with a banner that announced, "You see here ties and not violins. You see here bonbons and not marriages." Not to mention the girl greeting visitors with lewd poetry in Cologne. Two-dimensional works hung on walls, but threedimensional assemblages were propped up against walls and laid on the floor. Such spectacles flouted expectations of clarity and the easy distinction between individual elements. Unlike a simple installation of art, where the arrangement of 
works seeks to disappear, here it was impossible to ignore. The dadaists treated the space as a single unit, parallel to their magazines (and not unlike installation art from later in the twentieth century). Like their magazines, their exhibitions presented a Gesamtkunstwerk, or total work of art, an experience closer to that of the Cabaret Voltaire that brought together many forms to create what was no doubt an engulfing experience.

The dadaists' decision to show their journals and their manner of doing so propose a playful interrogation of the divisions between reproductions and originals, and between these media, especially since the publications feature collages that were also shown in the shows and that themselves were made up of cutouts from the journals. The dadaists' placements of the magazines - on tables, integrated into assemblages, and hung on walls - signal the journals' significance as artistically inventive publications, publicity materials, items for sale, and valuable records of the movement's history. The vertical display of the magazines, moreover, foregrounded how the horizontally oriented journals could inform the vertical, phenomenological experience provided by the exhibitions.

The dadaists goaded interaction, much as they had in their journals (Noordegraaf 16). The most extreme provocation for audience participation was in Cologne. Baargeld contributed "Fluid spectrum" (Fluidoskeptrik, c. 1920), an aquarium filled with blood red water, a woman's wig, a fake hand, and an alarm clock. An axe sat next to this bizarre assemblage, and a label told visitors to smash it. Ernst submitted a drawing with a note encouraging readers to write on it, thus countering the "do not touch" atmosphere typical of most galleries and museums. In Berlin, a sign hanging from the "Prussian Archangel" informed visitors that to understand the piece one had to perform military drills (Doherty "'See: We Are All Neurasthenics!"” 115). A text next to Dix's "Montage of Movable Figures" (Bewegliches Figurenbild, c. 1920) ordered visitors to grab it. In Paris, a hand-written sign addressed viewers directly: "This summer elephants will be wearing moustaches.... what about you?"10

Texts and images also foregrounded the dadaists' discursive presence, undermining the notion of a transparent display medium. ${ }^{11}$ The Dada organizers and artists participated in the spectacle, making their presence felt in the space, often by juxtaposing photographs of themselves with slogans and imperatives. In Berlin, a poster shows Hausmann's profile yelling, "Down with art!" "Finally open your mind!" and, "Free it for the demands of the times!" Heartfield's photo proclaims, "Down with art," and, "Down with bourgeois spirituality!" Another placard of Grosz declares, "Dada is the deliberate subversion of bourgeois terminology. Dada is on the side of the revolutionary proletariat!" This photo of Grosz appeared in Der Dada 3 and as an individual photograph in the show

10 Qtd. and translated in Sanouillet 203.

${ }^{11}$ Such tactics contrast with those of many museums, as described by Mieke Bal, in which the curator remains invisible and the works on view are silenced (Bal 165-66). 
(Bergius, appendix "First International Dada-Fair" 11, 30). Shouting at visitors, dadaists encouraged them to shout back, inviting a riotous state of affairs.

In Dada journals, manipulations of layout and typography encouraged readers to take note of the visual, printed nature of the words and forced them to actively discern how to combine and separate them. In the spatialized exhibition, interaction was also physical and mental, as visitors moved through the space, sometimes touching the artworks, having to distinguish between works on view and even between artworks and venue. These startling exhibitions called attention to the venues themselves, involving the walls and spaces of the shows in a manner that also countered presumptions about the neutrality of display supports and divisions between spectators and exhibits. The choice and treatment of the venues as well as their titles highlighted the conventions they were defying.

Each of these exhibitions was accompanied by a kind of catalogue that functioned as a secondary, supplemental source with a checklist of works shown, illustrations, and texts by participants. ${ }^{12}$ These printed publications were positioned between the exhibitions and the journals, and they signal a certain continuity in the dadaists' efforts in exhibition and design. In many ways these publications, which vary in length from four to sixteen pages, continue the kinds of tactics employed in both the journals and exhibitions. The Berlin catalogue, a poster-sized sheet folded into a booklet, is the most graphically daring. Printed in red and black, it contains texts printed in several directions overlying images. The cover of the Paris catalogue, which is identical to a poster advertising the show, presents a lively combination of typefaces, with letters in a random combination of upper and lower case letters and surrounded by sayings, printed on drawn placards and signs that read like passages in earlier journals: "No one is not supposed to be unaware of Dada," "athletes sought," and, "forget-me-not, please." The Cologne catalogue has a collage-like nature to it, with disparate texts ("Kosher for Passover" and "I do not have a cushion for my urn") and symbols (a tattooed hand and a U-shaped design) floating on the front and back covers. ${ }^{13}$

12 Dada-Vorfrühling: Gemälde, Skulpturen, Zeichnungen, Fluidoskeptrik, Vulgärdilettantismus (Cologne: Brauhaus Winter, 1920; Erste internationale Dada-Messe: Katalog (Berlin: Kunsthandlung Dr. Otto Burchard, 1920); Salon Dada: Exposition international (Paris: Galerie Montaigne, 1921).

13 The Cologne catalogue appeared in two editions. Both are rare. The copy described here, now in the Katherine Dreier Papers at the Beinecke Library at Yale University, is the first version. The second version replaces the Kosher reference and others about Jewish organizations with a reference to "Ass Wednesday." 


\section{The Journals' Continued Currency: Dada Journals, 1920-1921}

By the early 1920s, Tzara, Hausmann, Ernst, and the others no longer needed to depend on their journals to share works with one another, to communicate, or to publicize their movement. But they continued to value magazines as exhibition sites, as distinctive, viable means of artistic production and distribution and, increasingly, as venues for historicization. In April 1920, the month of their "Dada Early Spring" exhibition, Ernst and Baargeld produced Die Schammade, and Berlin dadaists Grosz, Heartfield, and Hausmann published Der Dada 3 two months prior to the landmark "Dada Fair." Tzara compiled Dada in Tirol (generally regarded as an eighth and final issue of Dada) in the Tyrolean Alps in Austria shortly after his Salon Dada closed, in September 1921. ${ }^{14}$

Whereas Cabaret Voltaire, Dada 1 and 2 could be understood as unofficial catalogues for exhibitions, the titles from 1920 and 1921 performed as creative venues in their own right, a parallel but distinctive display venue. Notwithstanding their diverse motivations, the editors of Die Schammade, Der Dada 3, and Dada in Tirol shared a recognition of the unique characteristics of the journal medium. Dada in Tirol bears little connection to the Salon Dada show, containing only a correction to the catalogue. He had used his earliest issues of Dada to establish ties with writers in Paris, but by 1920 he was living in Paris and was in close contact with leading members of the avant-garde there and elsewhere. Dada in Tirol reflects the fact that Dada was now an established movement and that Tzara had grown increasingly preoccupied with settling scores regarding the origins of Dada. A text by Arp emphatically, if nonsensically, asserts that Tzara invented the word, Dada: "I declare that Tristan Tzara found the word DADA on February 8, 1916, at 6 in the evening; I was present with my twelve children when Tzara pronounced for the first time this word which has aroused in us such legitimate enthusiasm." Tzara was still committed to expanding Dada and maintaining relations with Dada enthusiasts worldwide, however, and this publication bears signs of his ongoing commitment to Dada's transnationalism, as well. The full title, which can be interpreted as Dada Outdoors: The Singers' War in Tyrol (Dada Au grand Air: Der Sängerkrieg in Tirol), combines French and German words, and although most contributors lived in Paris, some originated from cities elsewhere.

The relationship between journal and exhibition is stronger in the case of the third issue of Der Dada and its editors' exhibition, the First International Dada Fair. Der Dada 3 presents a brief announcement of the exhibition and a profile photograph of Grosz that had been used in posters hung in the gallery space. It also contains Grosz's well-known collage and watercolor, 'Daum' marries her pedantic automaton 'George' in May 1920. John Heartfield is very glad of it (Meta-Mech.

14 In 1920, Tzara published the sixth and seventh issues of Dada, Bulletin Dada and Dadaphone. Dada in Tirol most closely relates to the Salon Dada exhibition. 
constr. nach [according to] Prof. R. Hausmann) (1920), which was on view at the Fair. In comparison to the works at the exhibition, fewer images by artists from outside Berlin appear in Der Dada 3. Yet this magazine nevertheless expresses the movement's global reach. It contains Picabia's "Manifeste Cannibale Dada," as well as various epigrams and gossip about Dada members that had appeared in Dadaphone (Paris, March 1920), the seventh issue of Tzara's Dada. In his essay, "Dada in Europa," Hausmann attributes the founding of Dada not only to Berlin dadaist Huelsenbeck, but also to Ball and Tzara. Page sixteen lists the Dada journals from Paris and Zurich. ${ }^{15}$

Of the three Dada groups, the Cologne dadaists most fully utilized the distinct advantages of the journal in the early 1920s. Ernst's and Baargeld's decision to publish Die Schammade at all indicates that this printed medium had become central to Dada practice. Like the Zurich dadaists in 1916 and 1917, these recent affiliates were particularly eager to connect with audiences in other cities and to situate themselves among more established artists in the Dada network. They depended on their magazines to achieve these goals. Ernst and Baargeld's exhibition primarily included submissions by themselves, along with fellow Cologne artist Willy Fick as well as Arp and Picabia. All catalogue texts are in German, more than half of the content is devoted to the list of works exhibited, and the target is a local audience. However both German and French texts appear in Die Schammade, which presents works by the Cologne group alongside pieces by dadaists from Paris and Berlin, namely Tzara, Georges Ribemont-Dessaignes, Louis Aragon, André Breton, Soupault, Paul Éluard, and Huelsenbeck, whose names are proudly printed on the cover. Advertisements for publications by members in Paris and Berlin announce their transnational connections and aspirations as well.

The editors of Dada in Tirol, Der Dada 3, and Die Schammade also continued to manipulate graphic design. These magazines include mechanically reproduced images and, to varying degrees, experimental typography and layout that render them interactive and destabilize the venue support. Although comparatively conventional, Dada in Tirol opens from the left rather than from the right, and all of the words of the title except for "Dada" are printed backwards and upside down. Der Dada 3 is particularly dazzling. Slogans, announcements, manifestoes, and essays in different font types and sizes are arranged in many directions to combine with collages, photographs, sketches, and what look like commercial photographs of banal subject matter such as a pair of socks and a spoon. The magazine is printed in black as well as red ink, texts appear in many directions, and drawings overlap drawings. Instead of numbers, each page is assigned a nonsequential measurement, such as "254 km," “4/1," “75\%," “1920," and "TOM 2."

15 Cannibale (Francis Picabia, Paris, 1920), Proverbe (Paul Eluard, Paris, 1920-1921), Der Zeltweg (Otto Flake, Walter Serner, and Tristan Tzara, Zurich, 1919). 


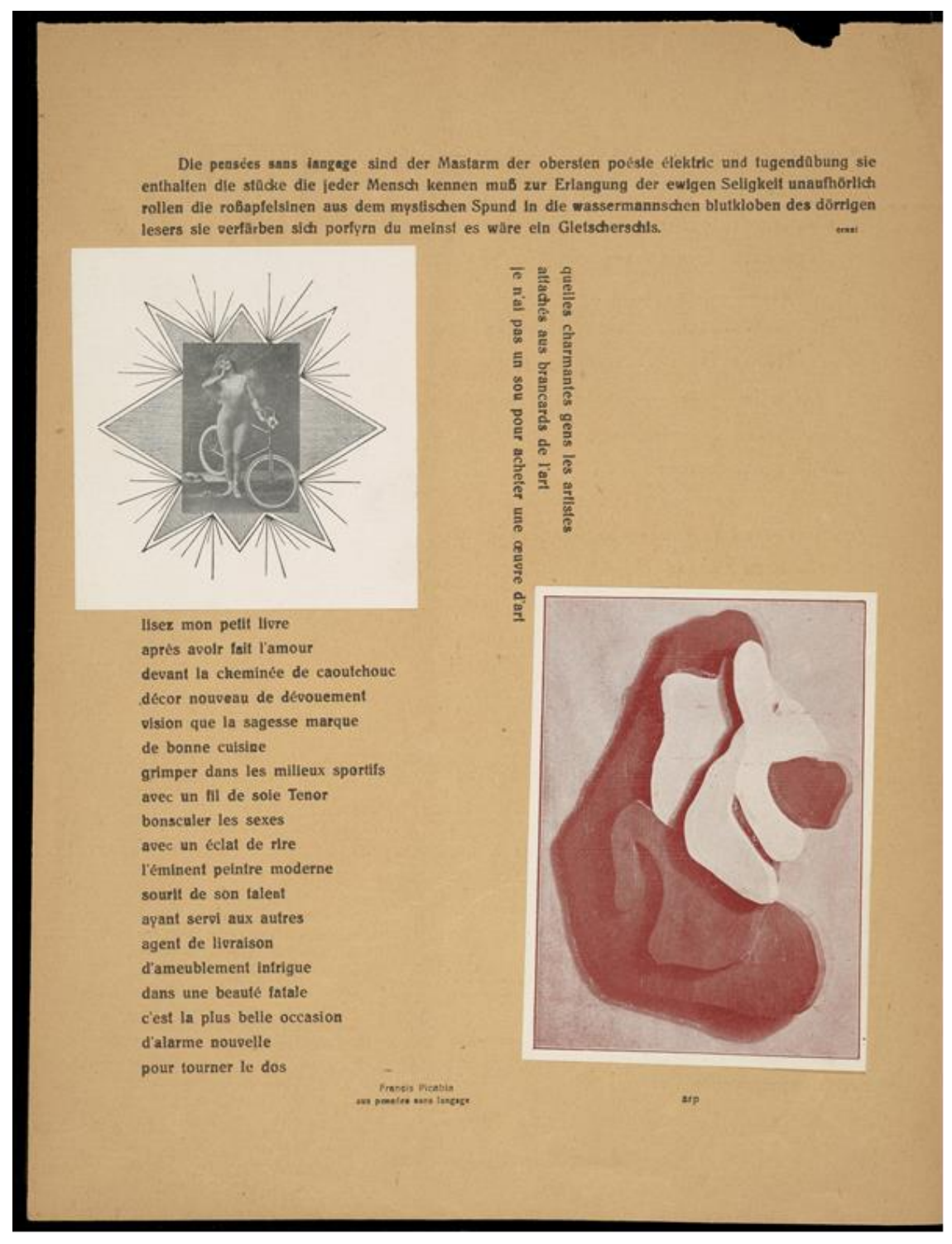

Figure 4: Page eight of Die Schammade, ed. Max Ernst and Johannes Baargeld (Cologne, April 1920). The Getty Research Institute, Los Angeles (85-S715). Image courtesy of the Getty Research Institute.

In Die Schammade typography and layout combine to lively effect, directly inspired by the Dada journals Ernst and Baargeld had received. For instance, here Tzara's poem, "Bulletin," is printed in many font types and sizes, mimicking its appearance in Dada 3. Many of the reproductions in Die Schammade are cutouts 
that have been pasted onto the page, so that they stand out from the texts, but the inclusion of pinup photographs among them points out that in fact all of them are reproductions and implies that they are of equal worth (fig. 4). The pink and sparkling paper stock used for some copies of the journal also calls attention to its framework. Regardless of their editors' exact motives, each of these magazines, like those before them, established the movement's emphasis on subverting standards of display and use of the journal to expand the movement. The journal remained a relevant site for creative experimentation.

In 1920 and 1921 the dadaists increasingly depended on their journals to legitimize and establish Dada, often with the aim of emphasizing the importance of a given center or individual. They became ever more cognizant of the comparatively long-lasting nature of printed materials, which is also apparent in the anthologies - Dadaco, Dadaglobe, and Dada Almanach - they set out to publish after the war. For them, these publications were closely tied to the journals and exhibitions. Although Dadaco and Dadaglobe were never realized, Huelsenbeck published Dada Almanach in 1920, to coincide with the end of the Dada Fair in Berlin. Tzara and Huelsenbeck began collecting materials for Dadaco in 1919, but disagreements between them resulted in their pursuing separate projects. ${ }^{16}$ This volume, along with correspondence and trial proofs of Dadaco, indicate that some of the content was the same as that of the journals, and Dada Almanach included photographs of the show in Berlin. They also reveal that interest in inventive graphic design remained high. Dadaco was to feature fragmented photographs, experimental typography, with words printed upside down or superimposed with arbitrary letters, and overlapping drawings and texts printed in red, green, blue, yellow, and black ink. In their efforts to establish their legacy in their journals, exhibitions, and anthologies, the dadaists maintained an emphasis on the innovative methods they had first developed in their journals.

\section{An Ongoing Legacy: Exhibition Design and Strategies of Display in the Twentieth Century and Beyond}

Artists affiliated with Dada continued to publish inventive art journals and organize exhibitions in the decades following the war. Dada Jazz, Dada Tank, 75 HP, and Mécano, as well as the surrealists' La Révolution surréaliste and the new series of Littérature, to name only a few, manifest the ongoing enthusiasm for the

\footnotetext{
${ }^{16}$ For more on these publications, see Sheppard, 5-8 and Heartfield et al. The full range of visual material intended for Dadaglobe was reassembled by Adrian Sudhalter in an exhibition, with accompanying catalogue, at the Kunsthaus Zurich in connection with Dada's centennial in 2016. See Sudhalter.
} 
medium. ${ }^{17}$ Figures such as Lissitzky and Duchamp stand out for their involvement with both printed publications and exhibitions. Among their notable undertakings are Lissitzky's review, Veshch-Gegenstand-Objet (1922-1923), his designs for the book, For the Voice (Dlia Golosa) (1923) and his work for the International Art Exhibition (Internationale Kunstausstellung) in Dresden (1926). Duchamp's singleissue journal, New York Dada, co-edited with Man Ray in 1921, his Exposition Internationale $d u$ Surréalisme at the Galerie Beaux-Arts in Paris (1938), and his collaboration on View magazine (David Hare, New York, 1942-1944) testify to his concurrent interests in the printed page and exhibition space. While many artists, curators, and editors moved toward an emphasis on clarity and contemplation at this time, graphic and exhibition design were valued and linked throughout the twentieth century. Thomas McEvilley asserts, "It has been the special genius of [the twentieth] century to investigate things in relation to their context, to come to see the context as formative on the thing, and, finally, to see the context as a thing itself" (7).

The dadaists' efforts were critical to this development. By the late 1900s, artists such as the Independent Group (IG), Fluxus, and Mail Artists began to put these strategies to ever more radical purposes, producing installation art and multiples for circulation through the postal service, both decisive reinventions of venue. Today Dada magazines serve as invaluable records of the dadaists' creative endeavors, but most importantly they manifest the dadaists' engagement with context and their keen recognition of the interconnected, multifaceted relationship between printed and exhibitionary means of display.

\section{Works Cited}

Altshuler, Bruce. "DADA ist politisch: The First International Dada Fair, Berlin, June 30-August 25, 1920." The Avant-Garde in Exhibition: New Art in the 20th Century. Ed. Bruce Altshuler. New York: Abrams, 1994. 98-115, 263-65. Print. Arp, Jean (Hans), "Déclaration," Dada in Tirol (Sept. 1921): 3. Trans. William Camfield. Francis Picabia: His Art, Life, and Times. Princeton: Princeton UP, 1979. 167. Print.

Bal, Mieke. "On Grouping: The Caravaggio Corner." Looking In: The Art of Viewing. Amsterdam: G+B Arts International, 2001. 161-90. Print.

Ball, Hugo. Flight Out of Time: A Dada Diary. Trans. Ann Raimes. Ed. John Elderfield. Berkeley: U of California P, 1996. Print. The documents of 20thCentury Art.

—. Introductory essay. Cabaret Voltaire (May 1916): 5. Print.

17 Dada Jazz (Dragan Aleksić, Zagreb, 1922); Dada Tank (Dragan Aleksić, Zagreb, 1922); 75 HP (Ilarie Voronca and Victor Brauner, Bucharest, 1924); Mécano (Theo Van Doesburg, Leiden, 1922-1924); La Révolution surréaliste (André Breton, Pierre Naville, and Benjamin Péret, Paris, 1924-1929); Littérature (André Breton, Paris, 1919-1921, new series 1922-1924). 
Benjamin, Walter. "The Work of Art in the Age of Mechanical Reproduction." Illuminations. Trans. Harry Zohn. New York: Schocken Books, 1969. Print.

Bergius, Hanne. Dada Triumphs! Dada Berlin, 1917-1923: Artistry of Polarities: Montages, Metamechanics, Manifestations. New York: G.K. Hall, 2003. Print. Crisis and the Arts 3.

Bury, Stephen. Breaking the Rules: The Printed Face of the European Avant Garde, 1900-1937. London: British Library, 2007. Print.

Dickerman, Leah. "Zurich." Dada: Zurich, Berlin, Hannover, Cologne, New York, Paris. Ed. Leah Dickerman. Washington: National Gallery of Art, 2005. 18-83. Print.

Doherty, Brigid. "Introduction to the First International Dada Fair," October 105 (Summer

2003): 97. Print.

. "'See: We Are All Neurasthenics!' or, The Trauma of Dada Montage." Critical Inquiry 24.1 (1997): 82-132. Print. https://doi.org/10.1086/448868

Drucker, Johanna. The Visible Word. Chicago: U of Chicago P, 1994. Print.

Greenberg, Reesa, Bruce W. Ferguson, and Sandy Nairne, eds. Thinking about Exhibitions. London: Routledge, 1996. Print.

Grieve, Alastair. "Arp in Zürich." Dada Spectrum: The Dialectics of Revolt. Ed. Stephen C. Foster and Rudolf E. Kuenzli. Madison: Coda Press; Iowa City: University of Iowa, 1979. 176-205. Print.

Hausmann, Raoul, ed. Der Dada 2 (Dec. 1919). Print.

Heartfield, John, Raoul Hausmann, George Grosz. [Dadaco trial sheets]. Dada germanico. Rome: Archivi d'arte del XX secolo; Milano: G. Massotta, 1970. Print. Documenti e periodici Dada.

Huelsenbeck, Richard. "Dada Lives," Transition: A Quarterly Review 25 (Fall 1936): 77-80. Rpt. New York: Kraus Reprint, 1967. Print.

Jauss, Hans Robert. "The Identity of the Poetic Text in the Changing Horizon of Understanding." Reception Study: From Literary Theory to Cultural Studies. Ed. James L. Machor and Philip Goldstein. New York: Routledge, 2001. 7-28. Print.

Klonk, Charlotte. Spaces of Experience: Art Gallery Interiors from 1800 to 2000. New Haven: Yale UP, 2009. Print.

Kriebel, Sabine T. “Cologne.” Dada: Zurich, Berlin, Hannover, Cologne, New York, Paris. Ed. Leah Dickerman. Washington: National Gallery of Art, 2005. 21473. Print.

Marinetti, F.T. "Marinetti an Ball, 5.7.1915, Rom." Dada 15/25: Post Scriptum oder Die Himmlischen Abenteuer des Hrn. Tristan Tzara une eine Suspensarium von Gerard Nitsche zu Elde Steeg \& Raoul Hausmann. Ed. Raoul Schrott. Innsbruck: Haymon-Verlag, 1992. 22. Print.

McEvilley, Thomas. Introduction. Inside the White Cube: The Ideology of the Gallery Space. By Brian O'Doherty. Santa Monica: Lapis P, 1986. 7-12. Print. 
Mileaf, Janine, and Matthew S. Witkovsky. "Paris." Dada: Zurich, Berlin, Hannover, Cologne, New York, Paris. Ed. Leah Dickerman. Washington: National Gallery of Art, 2005. 346-409. Print.

Noordegraaf, Julia. Strategies of Display: Museum Presentation in Nineteenthand Twentieth-Century Visual Culture. Rotterdam: Museum Boijmans Van Beuningen: NAi, 2004. Print.

Prampolini, Enrico. Letter to Tristan Tzara. 17 March 1917. TZRC 3118. Fonds Tristan Tzara, Bibliothèque Littéraire Jacques Doucet, Paris. MS.

Sanouillet, Michel. Dada in Paris. Trans. Sharmila Ganguly. Cambridge, MA: MIT $P, 2009$. Print.

Schnapp, Jeffrey T. "Epic Demonstrations: Fascist Modernity and the 1932 Exhibition of the Fascist Revolution." Fascism, Aesthetics, and Culture. Ed. Richard J. Golsan. Hanover, NH: UP of New England, 1992. 1-37. Print.

Sheppard, Richard, ed. Zürich - Dadaco - Dadaglobe: The Correspondence between Richard Huelsenbeck, Tristan Tzara and Kurt Wolff (1916-1924). Fife, Scotland: Hutten P, 1982. Print.

Simmons, Sherwin. "Advertising Seizes Control of Life: Berlin Dada and the Power of Advertising." Oxford Art Journal 22, 1 (1999): 121-146. https://doi.org/10.1093/oxartj/22.1.119

Steinberg, Leo. "Other Criteria." Other Criteria: Confrontations with TwentiethCentury Art. New York, Oxford UP, 1972. 55-91. Print.

Sudhalter, Adrian. Dadaglobe Reconstructed. Zurich: Kunsthaus Zürich ; Scheidegger \& Spiess, 2016. Print.

Tzara, Tristan. "Chronique Zürichoise." CEuvres complètes. Vol. 1. Ed. Henri Béhar. Paris: Flammarion, 1975. 561-68. Trans. "Zurich Chronicle" The Dada Painters and Poets: An Anthology. Ed. Robert Motherwell. Boston: G.K. Hall, 1981. 235-42. Print.

—. “Manifeste Dada 1918." Dada 3 (1918): 1-3. Trans. “Dada Manifesto 1918." The Dada Painters and Poets: An Anthology. Robert Motherwell, ed. Boston: G.K. Hall, 1981, 76-82. Print.

—. "Les Revues d'avant-garde." CEuvres complètes. Vol. 1. Ed. Henri Béhar. Paris: Flammarion, 1975. 509. Print. 